\title{
VITAMIN A IN TESTICULAR TISSUE OF THE BOAR AND INTERSEX PIG
}

\author{
W. D. BOOTH \\ A.R.C. Unit of Reproductive Physiology and Biochemistry, \\ University of Cambridge*
}

(Received 28th March 1974)

In mammals suffering from vitamin A deficiency, the testes show various degrees of atrophy associated with a reduction in spermatogenic activity (Moustgaard, 1969). Coward, Howell, Pitt \& Thompson (1966) and Palludan (1966a) demonstrated that this effect of vitamin A deficiency is not related to an endocrine deficiency, and Palludan (1966b) in the boar and Ahluwalia \& Bieri (1971) in the rat showed that it is due to a direct effect on the process of spermatogenesis. The same investigators observed that in animals whose rate of growth and health were maintained on retinoic acid (vitamin A acid), testicular lesions still occurred. Injections of retinol (vitamin A alcohol), or retinaldehyde (vitamin A aldehyde) made directly into the testes restored spermatogenesis at the site of injection. Little information is available on the levels of endogenous vitamin $\mathrm{A}$ in testis in relation to the development and maintenance of spermatogenesis, and the purpose of this communication is to present such data obtained from studies on boar testis and testicular tissue of the intersex pig.

Gonads were obtained within 30 min of slaughter from a number of boars and intersex pigs of different ages (see Tables 1 and 2). Samples were fixed in Bouin's fluid for histology, and the paraffin wax-embedded sections were stained with Delafield's haematoxylin and chromatrope 2R; the remainder of the tissue was frozen over solid $\mathrm{CO}_{2}$ until required for the assay of vitamin $\mathrm{A}$ and steroids. For this purpose, a maximum of $50 \mathrm{~g}$ testicular tissue was taken and homogenized for $5 \mathrm{~min}$ in water $(100 \mathrm{ml})$. The homogenate was added to $70 \%$ aqueous ethanol $(200 \mathrm{ml})$ and the mixture was left overnight at $+4^{\circ} \mathrm{C}$. After centrifugation $(22,902 \mathrm{~g})$ for $20 \mathrm{~min}$ at $+4^{\circ} \mathrm{C}$, the supernatant was reduced to $20 \mathrm{ml}$ under reduced pressure and then extracted with redistilled diethyl ether $(3 \times 60 \mathrm{ml})$. The combined ether extracts contained some vitamin $\mathrm{A}$ and free steroids and the aqueous phase contained steroid conjugates (an account of the steroid investigations is in preparation). The ether extract was evaporated to dryness, combined with the tissue pellet remaining after centrifugation and subjected to alkaline hydrolysis according to Mervyn \& Morton (1959). The reaction mixture was extracted with redistilled diethyl ether $(5 \times 250 \mathrm{ml})$, washed with water to about $\mathrm{pH} 7$, dried over anhydrous $\mathrm{Na}_{2} \mathrm{SO}_{4}$ and the ether was removed under reduced pressure. The dry material was dissolved in a small quantity of light petroleum ( 40 to 60 b.p.) and lipids were removed by 'freezing

* Postal address: Animal Research Station, 307 Huntingdon Road, Cambridge CB3 0JQ. 
out' at $-20^{\circ} \mathrm{C}$. After centrifugation $(26,838 \mathrm{~g})$ for $20 \mathrm{~min}$ at $-10^{\circ} \mathrm{G}$, the supernatant was brought to $20 \mathrm{ml}$ with further solvent and extracted with $83 \%$ aqueous methanol $(6 \times 20 \mathrm{ml})$. The combined methanol extracts were evaporated to dryness and submitted to thin-layer chromatography using silica gel impregnated with fluorescein; the solvent systems used by Gower (1964) were found suitable for separating retinol from $\mathrm{C}_{19}$ steroids (see Plate 1). Retinol was

Table 1. Vitamin A in boar testes

\begin{tabular}{|c|c|c|c|c|c|}
\hline Age & Breed & $\begin{array}{c}\text { Boars } \\
\text { (testes assayed) }\end{array}$ & $\begin{array}{l}\text { Total wt of } \\
\text { testes per } \\
\text { animal }(\mathrm{g})\end{array}$ & $\begin{array}{l}\text { Vitamin } A \\
\text { (i.u. } / 100 \mathrm{~g} \\
\text { of testes })^{*}\end{array}$ & $\begin{array}{c}\text { Stage } \\
\text { of } \\
\text { spermatogenesis }\end{array}$ \\
\hline At birth & $\mathbf{L W} \times \mathbf{E s x}$ & Pooled (12) $\dagger$ & $0.41 \ddagger$ & Trace & Gonocytes \\
\hline 6 weeks & LW $\times$ Esx & Pooled (12) $\dagger$ & $7 \cdot 44 \ddagger$ & $22 \cdot 5 t$ & Gonocytes \\
\hline 12 weeks & $\mathbf{L W} \times \mathbf{E s x}$ & Pooled (4) $\dagger$ & $19 \cdot 2 \ddagger$ & $37 \cdot 7 \ddagger$ & Spermatogonia \\
\hline 18 weeks & $\begin{array}{l}\mathrm{LW} \times \text { Esx } \\
\mathrm{LW} \times \text { Esx }\end{array}$ & $\begin{array}{l}\text { C11 } \\
\text { C13 }\end{array}$ & $\begin{array}{l}57 \cdot 6 \\
125\end{array}$ & $\begin{array}{l}113 \\
82 \cdot 6\end{array}$ & $\begin{array}{l}\text { Few } \\
\text { spermatozoa }\end{array}$ \\
\hline 24 weeks & $\begin{array}{l}\mathrm{LW} \times \text { Esx } \\
\mathrm{LW} \times \mathrm{Esx}\end{array}$ & $\begin{array}{l}\text { A39L } \\
\text { B50C }\end{array}$ & $\begin{array}{l}305 \\
354\end{array}$ & $\begin{array}{l}76 \cdot 7 \\
79 \cdot 3\end{array}$ & \\
\hline 30 weeks & $\begin{array}{l}\mathrm{Ldr} \\
\mathrm{LW} \\
\mathrm{LW} \times \mathrm{Esx} \\
\mathrm{LW} \times \mathrm{Esx}\end{array}$ & $\begin{array}{l}340 \\
230 G \\
\text { B36M } \\
\text { B37M }\end{array}$ & $\begin{array}{l}477 \\
542 \\
533 \\
427\end{array}$ & $\begin{array}{c}75 \cdot 5 \\
61 \cdot 1 \\
107 \\
61 \cdot 0\end{array}$ & $\begin{array}{l}\text { Abundant } \\
\text { spermatozoa }\end{array}$ \\
\hline 36 weeks & $\begin{array}{l}\mathrm{LW} \times \mathrm{Esx} \\
\mathrm{LW} \times \mathrm{Esx}\end{array}$ & $\begin{array}{l}R \\
G\end{array}$ & $\begin{array}{l}465 \\
478\end{array}$ & $\begin{array}{l}63 \cdot 0 \\
47 \cdot 7\end{array}$ & \\
\hline 2 years & $\begin{array}{l}\mathrm{LW} \times \mathrm{Ldr} \\
\mathrm{LW} \times \mathrm{Esx}\end{array}$ & $\begin{array}{l}\text { A } \\
\text { B }\end{array}$ & $\begin{array}{r}1004 \\
935\end{array}$ & $\begin{array}{l}54 \cdot 3 \\
92 \cdot 0\end{array}$ & \\
\hline
\end{tabular}

LW, Large White; Esx, Essex; Ldr, Landrace.

* Uncorrected for losses. $†$ No. of animals. $\ddagger$ Mean.

Table 2. Vitamin A in the testicular tissue of intersex pigs

\begin{tabular}{|c|c|c|c|c|c|}
\hline \multirow{2}{*}{ Pigno. } & \multirow{2}{*}{ Age } & \multicolumn{2}{|c|}{ Gonad* } & \multirow{2}{*}{$\begin{array}{l}\text { Total wt of } \\
\text { testicular tissue } \\
(\mathrm{g})\end{array}$} & \multirow{2}{*}{$\begin{array}{c}\text { Vitamin } A \\
\text { (i.u. } 1100 \mathrm{~g} \text { of } \\
\text { testicular tissue })\end{array}$} \\
\hline & & Left & Right & & \\
\hline $\begin{array}{l}\text { B58 } \\
\text { D16B } \\
\text { A20B } \\
\text { D18B } \\
\text { B16M } \\
\text { D17B } \\
\text { A17M }\end{array}$ & $\begin{array}{c}36 \text { to } 52 \text { weeks } \\
36 \text { to } 52 \text { weeks } \\
1 \text { year } \\
36 \text { to } 52 \text { weeks } \\
1 \text { year } \\
36 \text { to } 52 \text { weeks } \\
1 \text { year }\end{array}$ & $\begin{array}{l}\text { Ovotestis } \\
\text { Ovary } \\
\text { Ovotestis } \\
\text { Ovary } \\
\text { Ovary } \\
\text { Testis } \\
\text { Testis }\end{array}$ & $\begin{array}{l}\text { Ovotestis } \\
\text { Ovotestis } \\
\text { Testis } \\
\text { Ovotestis } \\
\text { Ovotestis } \\
\text { Testis } \\
\text { Testis }\end{array}$ & $\begin{array}{c}18 \cdot 6 \\
23 \cdot 5 \\
28 \cdot 5 \\
43 \cdot 5 \\
56 \cdot 1 \\
171 \\
209\end{array}$ & $\begin{array}{c}7 \cdot 70 \\
\text { Trace } \\
8 \cdot 53 \\
18 \cdot 9 \\
16 \cdot 0 \\
32 \cdot 0 \\
4 \cdot 87\end{array}$ \\
\hline
\end{tabular}

* Germinal cells absent in testicular portion of gonad.

$\dagger$ Uncorrected for losses.

located under u.v. light $(254 \mathrm{~nm})$ and subsequently eluted with chloroform: ether $(1: 1, \mathrm{v} / \mathrm{v} ; 2 \times 5 \mathrm{ml})$. The solvent was removed under reduced pressure and the extract taken up in chloroform $(1 \mathrm{ml}) ; 0.3-\mathrm{ml}$ samples were taken in duplicate for the spectrophotometric determination of vitamin A (Glover, Goodwin \& Morton, 1947). The recovery of the method was approximately $25 \%$.

The results are presented in Tables 1 and 2. The testicular extract of boars at 


\section{PLATE 1}

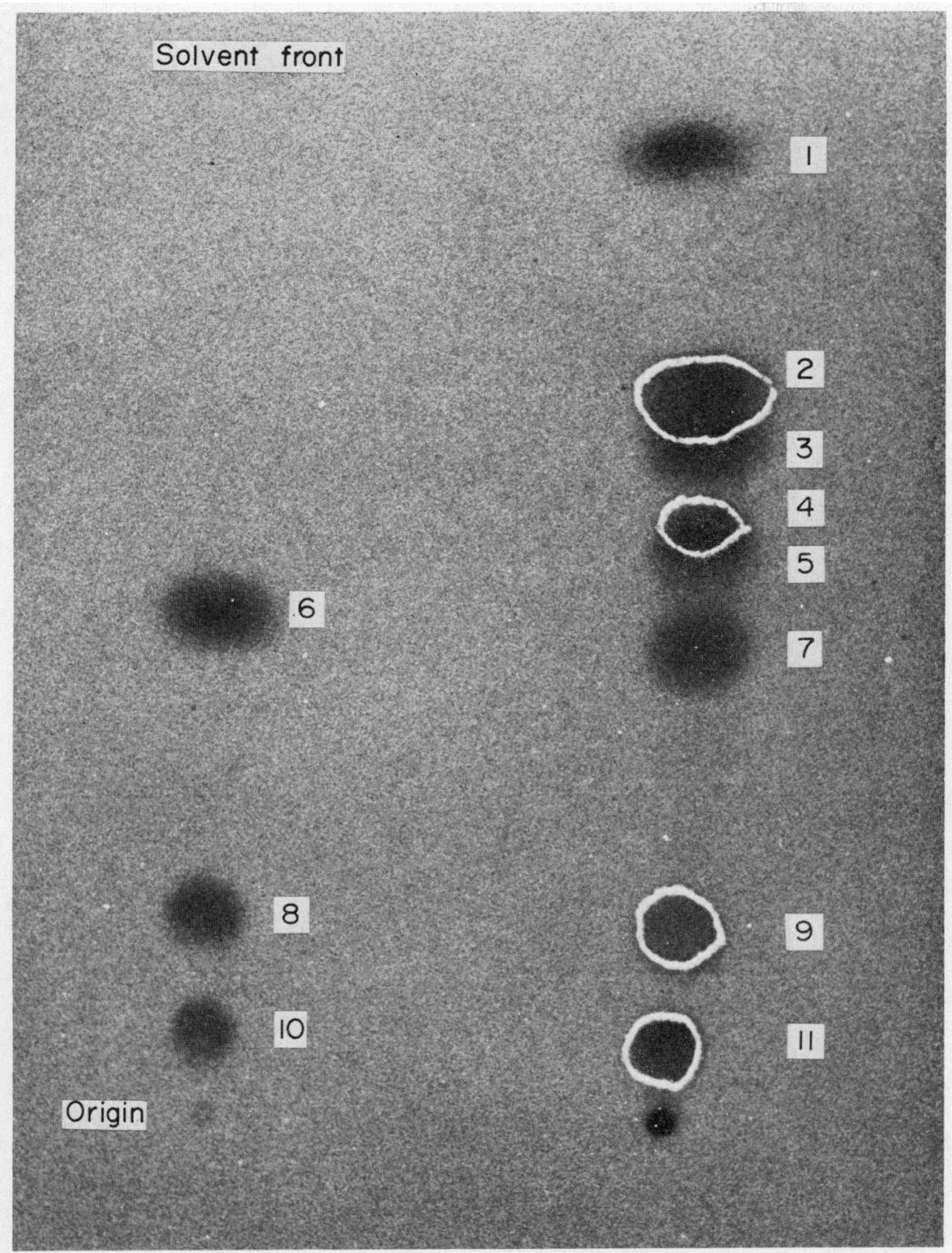

'The separation on thin-layer chromotography of authentic retinol (spot 4), Cio steroids and 16 -unsaturated $\mathrm{C}_{19}$ steroids which were studied in pig testis. Solvent system toluene: ethyl acetate $(9: 1, v / v ; \times 2)$ and benzene : ether $(9: 1, v / v)$ after Gower $(1964)$. Compounds located by u.v. light (outlined) and cthanol: $\mathrm{H}_{2} \mathrm{SO}_{4}(1: 1 . \mathrm{v} / \mathrm{v})$. (1) $5 \mathrm{x}$-Androst16-en-3-onc; (2) 4,16-androstadien-3-one; (3) 5x-androst-16-en-3x-ol; (4) vitamin A

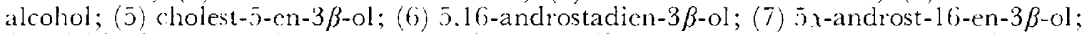

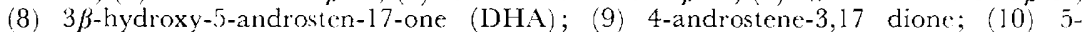
androstene-3 $\beta .17 \beta$-diol; (11) $17 \beta$-hydroxy-4-androsten-3-one (testosterone).

(Facing f). 220) 
birth produced a faint fluorescence which corresponded to retinol on the thinlayer chromatogram, but the amounts were below the sensitivity of the assay method. Between 12 and 24 weeks of age, spermatogenesis became established and the concentration of vitamin A reached maximum levels, coincident with the appearance of spermatozoa; the high levels of vitamin A were maintained in older boars showing active spermatogenesis. The concentration of vitamin A in the testicular extracts of all intersex pigs was lower than that found in the testes of normal boars during or after puberty; furthermore, there was no obvious correlation between the levels of vitamin A and testicular weight or age in the intersex pigs. The right testis of intersex pig A17M was in the scrotal position; this testis had well-developed seminiferous tubules with large lumina. The left testis of pig A17M and the gonads of the other intersex pigs were intraabdominal; the seminiferous tubules rarely had a lumen. Only Sertoli-like cells were present in the seminiferous tubules of the intersex gonad, a distinctive characteristic of such gonads (Breeuwsma, 1970).

The data presented here support the view that vitamin $\mathrm{A}$ is intimately associated with spermatogenesis. The difference between the levels of vitamin A in boar testis and in the testicular tissue of intersex pigs suggests that it might be the germinal cells which are responsible for an additional accumulation of vitamin in boar testis. It is unlikely that the lack of germinal cells in the testicular tissue of intersex pigs is a direct consequence of a vitamin A deficiency. A more likely explanation is the influence of genetic anomalies (Fechheimer, 1970) and the intra-abdominal location of the gonad (Waites \& Setchell, 1969). Subsequent endocrine studies on the intersex pig in this laboratory have shown that the lower levels of vitamin $A$ in the testis do not affect the steroid production of this tissue. The need for vitamin $\mathrm{A}$ in spermatogenesis is probably similar to that required by other proliferative tissues (Fell, 1969); the underlying mechanism perhaps involves a specific effect of vitamin A on cell membranes (Lucy, 1969) and lysosome stability (Roels, 1969).

The author is indebted to Dr W. A. Coward of the Dunn Nutritional Laboratory, Cambridge, for his helpful suggestions.

\section{REFERENGES}

Ahluwalia, B. \& BiERI, J. G. (1971) Local stimulatory effect of vitamin A on spermatogenesis in the rat. F. Nutr. 101, 141.

Breeuwsma, A.J. (1970) Studies on Intersexuality in Pigs. Diss. Drukkerij Bronder-Offset N.V., Rotterdam. Coward, W. A., Howell, J. McG., Pirt, G. A. J. \& Thompson, J. N. (1966) Effects of hormones on reproduction in rats fed a diet deficient in retinol (vitamin $\mathrm{A}$ alcohol) but containing methyl retinoate (vitamin A acid methyl ester). F. Reprod. Fert. 12, 309.

FECHHEImer, N. S. (1970) Genetic aspects of testicular development and function. In The Testis, Vol. 3, p. 1. Eds. A. D. Johnson, W. R. Gomes and N. L. VanDemark. Academic Press, New York and London.

FeLL, H. B. (1969) Introduction to Session III, International Symposium on the Metabolic Function of Vitamin A. Am. F. clin. Nutr. 22, 975.

Glover, J., Goodwin, T. W. \& Morton, R. A. (1947) Studies of vitamin A. 1. A chromotographic method for separating free and esterified vitamin A. Biochem. 7. 41, 94.

Gower, D. B. (1964) Chromatographic separation of $\mathrm{C}_{19}$-16-dehydrosteroids. F. Chromat. 14, 424.

Lucy, J. A. (1969) Some possible roles for vitamin A in membranes: micelle formation and electron transfer. Am. F. clin. Nutr. 22, 1033. 
Mervyn, L. \& Morron, R. A. (1959) Unsaponifiable fraction of lipid from normal and diseased human kidney. Biochem. F. 72, 106.

MoustgaARD, J. (1969) Nutritive influences upon reproduction. In Reproduction in Domestic Animals, 2nd edn, p. 489. Eds. H. H. Cole and P. T. Cupps. Academic Press, New York and London.

Palludan, B. (1966a) A-avitaminosis in Swine. Munksgaard, Copenhagen.

Palludan, B. (1966b) Direct effect of vitamin A on boar testis. Nature, Lond. 211, 639.

RozLs, O. A. (1969) The influence of vitamin A and E on lysosomes. In Lysosomes in Biology and Pathology, Vol. 1, p. 254. Eds. J. T. Dingle and H. B. Fell. North-Holland Publishing Co., Amsterdam.

Wartes, G. M. H. \& Setchell, B. P. (1969) Some physiological aspects of the function of the testis. In The Gonads, p. 649. Ed. K. W. McKerns. North-Holland Publishing Go., Amsterdam. 